\title{
Marketing Politics: Political Participation of Beginner Voters In Electing The President of 2019
}

\author{
Runik Machfiroh $^{1)}$, Ama Suyanto ${ }^{2)}$ \\ Lecture of civic Study Program of Visual Communication Design Faculty of Creative Industries \\ Universitas Telkom \\ Lecture of Marketing Management Study Program Faculty of Economics and Business Universitas \\ Telkom, Jl. Telekomunikasi No.1, Dayeuh Kolot, Bandung 40257 \\ runikmachfiroh@telkomuniversity.ac.id ${ }^{1)}$, ama@telkomuniversity.ac.id ${ }^{2)}$
}

\begin{abstract}
Political marketing in the 2019 presidential election is one of the main factors of Indonesian democracy. The brand personality of the 2019 presidential candidates became an important point in the victory of the 2019 presidential election. The millennial generation is part of the target of novice voters. Previous research has carried out mapping and analysis of political marketing in the 2014 presidential election, 2014 legislative elections, and the 2015 regional elections where in each election there were differences in emphasis in political marketing. The purpose of this study is to analyze the uniqueness of political marketing in the 2019 presidential election compared to previous political marketing. This research approach uses quantitative research with descriptive methods with statistical descriptive data analysis. The population of this research is novice voters in West Java. The sampling technique used was random sampling with a total sample of 100 respondents. The results of this study indicate that $100 \%$ of beginner voters use digital media to find out presidential candidates and $80 \%$ to add to their basic political knowledge. However, the presidential election decision based on the media only reached $57.6 \%$.

Keywords: Political Marketing, Political Participation, Political Education, Beginner Voters, Presidential Elections
\end{abstract}

\begin{abstract}
Abstrak. Marketing politik dalam pemilihan Presiden Tahun 2019 menjadi salah faktor utama demokrasi Indonesia. Brand personality dari kandidat calon presiden 2019 menjadi poin penting dalam kemenangan pemilihan presiden 2019. Generasi milenial adalah bagian dari target pemilih pemula. Penelitian sebelumnya telah dilakukan pemetaan dan analisis marketing politik pada pemilihan presiden 2014, pemilihan legislatif 2014, dan pemilihan kepala daerah 2015 di mana dari setiap pemilihan terjadi perbedaan penekanan dalam marketing politik. Tujuan penelitian ini adalah menganalisis keunikan marketing politik pemilihan presiden tahun 2019 dibanding marketing politik sebelumnya. Pendekatan penelitian ini menggunakan penelitian kuantitatif dengan metode deskriptif dengan analisis data deskriptif statistik. Populasi penelitian ini adalah pemilih pemula di Jawa Barat. Teknik sampling yang digunakan adalah random sampling dengan total sampel 100 responden. Hasil penelitian ini menunjukkan bahwa $100 \%$ pemilih pemula menggunakan media digital untuk mengetahui calon presiden dan $80 \%$ untuk menambah pengetahuan dasar politik. Namun, keputusan pemilihan presiden berdasarkan media hanya mencapai $57.6 \%$.
\end{abstract}

Kata Kunci: Marketing Politik, Partisipasi Politik, Pendidikan Politik, Pemilih Pemula, Pemilihan Presiden 


\section{INTRODUCTION}

The election process plays an important role in the democratic system. Elections are the main mechanism that implements the principle of popular sovereignty. The highest authority is those who delegate authority to the representatives of political parties in the electoral process. Elections provide a space for citizens to participate in channelling voting rights over their sovereignty. Participation in elections guarantees a faithful representation of the will of the people and thus prevents distortion. Citizens' participation in elections confirms their support for changes in the life of the nation as well as life in the political order. This promotes not only the stability of citizens' political processes but also inherently desirable for normative reasons. According to democratic theory, the right to vote in elections is not only universally guaranteed but also must be done to guarantee the rights of citizens in politics. The involvement of young people in politics can take various forms, as can other age groups. Elections are only one element of a far broader repertoire of political participation, and the most fundamental democratic action that must be taken. Young people must choose to ensure the total amount.
Novice voters in the digital era or millennial generation have their own positioning in political marketing. Indonesia, if its democracy wants to advance and be civilized, it needs special management or political education for first-time voters. In contrast to advanced democracies, the level of youth voter participation in developing countries appears to be higher, except for the Philippines where competitive and regular elections have been held since 1992, but the quality of governance has proven disappointing. The high participation of Mongolian youth is mainly due to the new installation of democratic elections. For citizens who have been governed under Soviet Mongolia, a new democratic mechanism that inspires them to participate in politics.

The general elections to be held in 2019 for presidential or legislative elections both central and regional provide opportunities for novice voters to build and develop a fresher and enjoyable logistics process. In many studies found the participation of beginners who were rejected. This young group is growing unconcerned about the country's political development. They prefer to participate in egalitarian politics, namely through various social activities that accept social, moral giving to marginalized groups. To win the votes of novice voters, special strategies are needed so that what young groups do synergize with the interests of candidates for president and vice president. 
Using attractive recruitment methods and multimedia strategies to attract the attention of young people is one of the attractive choices that can be used to attract them to vote in elections.

The voters are indeed not only Indonesian viewers, but several countries including the United States also provide a sizable portion in managing novice voters controlled by young people. The inclusion of youth in important formal politics, approved by the popular uprising of the United States in 2011/2012 and the various occupation movements have been renewed, making the government and political parties increase the youth's potential. When the youth-provoked protests have agreed to the authoritarian regime of the authorities, significant disagreements will arise if young people are not included in new formal decision making. This can disrupt transitions and increase conflict transitions. The international community has agreed to debate about the political system, including through several international conventions and UN resolutions. In line with this commitment, UNDP views youth as a positive force for transformative social change and supports the promotion of youth political participation. The basic principle is support for political participation which must support the election cycle. Capacity building for young candidates has proven to be more effective as ongoing support than once three months before the election.
Young people who are actively involved in their communities from the beginning are more likely to be involved, citizens and voters.

Novice voters have always been the target of political parties. Novice voters are constructed as unstable voters and are easy to influence. The constitution number 7 of 2017 concerning Elections states that the condition for a person to be a voter is an Indonesian citizen who is even 17 (seventeen) years of age or older, has been married, or has already been married. Thus a person said to be a novice voter is those who are 17 years old on voting day, have never voted, or those who are married or never married even though they have not reached the age of 17 years and have never used their voting rights. The number of first-time voters as mentioned by the general election commission (KPU) is quite potential, they are spread out in all corners with various dynamics and diverse cultures. Based on the problem above, novice voters need a formula in political marketing so that the level of participation is high and the quality of elections increases.

\section{RESEARCH METHODS}

Research approach through quantitative. This research method was a quantitative descriptive. Data collection techniques with purposive sampling, which was based on the object of research were the novice voter. The object of this research was 
the first time voters who had used their right to vote in the 2019 Presidential Election in Bandung City randomly. The research sample was Telkom University students who are beginner voters in the city of Bandung from a total population of 215 first-rate students from the city of Bandung, then the sample obtained by 100 students with open distribution via a google form.

\section{DISCUSSION}

Data collection via Google Form to collect data from various universities in Indonesia. Questionnaires are distributed online, especially the ig and Whatsapp groups. In total, 100 respondents were used to descriptively measure the participation of novice voters. Categories of respondents between 17 to 24 years are $100 \%$ with the most education, namely 59\% at the undergraduate level. Most respondents came from middleclass families (26.04\%) and upper-class families $(29.95 \%)$ which indicated that respondents had good financial status while $10.94 \%$ of respondents had a low income per month. Most of the education level of the respondent's parents is higher than in secondary school. Then, respondents are grouped by type of social media. Of the total respondents, 196 respondents were chosen from 3 to 5 types of social media $(51.04 \%)$, followed by respondents who chose less than 3 types of social media and more than 5 types of social media. Respondents prefer to use Line,
Blog to read news about politics, followed by Instagram, Youtube, Facebook, Twitter and Wikipedia. Besides, respondents were also grouped by duration in using social media. The longest duration of using social media is over 2 hours, there is $54.2 \%$.

Instagram to see politicians' official accounts or about political news. Political practice activities on Instagram inform users about their lifestyle where they attract users to view posts. Similar to this research, a previous study found novice voters had participated in offline activities, but increased political knowledge from social media. Based on the results of Schroeder's research in Machfiroh (2018) in four countries namely Sweden, China, America and India on media and politics shows that the presence of digital media has increased citizens' knowledge because digital media has become a medium of mediation between political elites and political elites with citizens. This is reinforced by the opinion of Assard and Bennet in Machfiroh (2018), that digital media in politics has become a marketplace of ideas. Likewise in Indonesia, the results of research by Suyanto and Machfiroh (2016) show that political marketing in the 2015 local elections simultaneously in Indonesia has shifted through digital media and has influenced the decision of novice voters. The use of information on social media encourages participatory activities. Information search activities create awareness of people to 
participate online and offline in politics. Also, people who discuss politics through offline and online tend to have a higher level of willingness to accept political risks, so that they can attentively participate in participating politics both online and offline. Online and offline discussions also raise awareness of young adults to participate in politics and direct them to monitor the government. For example, many young people ask about Bandung facilities or social problems in Ridwan Kamil's official account. However, it is estimated based on previous research that political trust does not mediate the relationship between information seeking and online and offline political participation where young adults have low trust in news and information about politics through social media. In Indonesia, many social media accounts present untrue news and some of them cause social conflicts between users. For example, sharing media such as Instagram, Facebook and YouTube provide users to freely upload all political content that may contain negative and invalid information. Therefore, negative information online might reduce the political trust of young adults.

The political party's target of novice voters is based on the condition of novice voters who are considered capable of being governed and herded in determining their choices. Unfortunately, the patterns of recruitment of votes of novice voters by political parties often do not pay attention to both age and the dynamics of novice voters. M. Rusli Karim (1991) views beginner voters, who are mostly young people, who are difficult to dictate, even suspected as one of the groups that are difficult to be approached by political parties. Novice voters do not yet have adequate political literacy, only tend to follow the trends in their neighbourhood. Suhartono (2009). Recording beginner voters has a cultural value that is relaxed, free, and tends to be informal and fun-seeking, with the government having to develop activities that allow novice voters to pursue their own political forms. They do not have to follow the forms of political participation formed by political parties so that their freedom is shackled, but must encourage and inspire them to pursue their forms of participation and activities. Activities do not have to be "political", but "mutually beneficial". By participating in activities that meet their needs, they can not only help others but also gain fulfilment from their contributions, as well as make decisions to choose according to their aspirations. This means that the voice will complement other voices to political parties that are able to strengthen their empowerment. Political party campaign activities must energize novice voters to engage in serious social problems, allow them to practically help children in need and allow young volunteers to chat with each other to share their experiences. Campaign activities must inspire, novice voters who are mostly young people not only 
listen to and override the campaign, they can even contribute and produce real change. Structurally the government should try to include young voters in the decision-making process and empower them to have more votes in actions related to their own interests. Political parties and governments can promote electronic participation in politics, including online discussions, visual associations, and political chat rooms. The use of information technology will encourage the political participation of novice voters so that they feel comfort, accessibility, create new mechanisms to regulate associations, and convey information without government intervention.

\section{CONCLUSION}

Political participation of novice voters in the 2019 presidential election related to the media used in increasing beginner participation by $100 \%$ to find out about presidential candidates and $80 \%$ to increase basic political knowledge. However, the presidential election decision based on the media only reached $57.6 \%$.

\section{REFERENCES}

[1] Amirullah dan Budiono, Harris. (2013). Pengantar Manajemen. Edisi Ketiga Penerbit Graha Ilmu.

[2] Fukuyama, Francis., (2001) Sosial Capital; Civil Society and Development, Third World Quarterly, Vol 22.

[3] Henn, Matt, Mark Weinstein, and Dominic Wring. (2002). "A Generation Apart? Youth and Political Participation in Britain." British
Journal of Politics and International Relations, Vol. 4(2):167-92 12.

[4] Henn, Matt, Mark Weinstein, and Dominic Wring. (2005). "Uninterested Youth? Young People's Attitudestowards Party Politics in Britain.” Political Studies, Vol. 53: 556- 57 (2005).

[5] M. Rusli Karim. (1991). Pemilu Demokratis Kompetitif. Yogyakarta: PT Tiara Wacana Yogya.

[6] Machfiroh, Runik. (2018). Pendidikan Kewarganegaraan di Era Digital. Disertasi PKn UPI tidak diterbitkan

[7] Norris, Pippa. (2003). 'Young People and Political Activism: From the Politics of Loyalties to the Politics ofChoice?', Paper presented to the Council of Europe Symposium, Young People and Democratic Institutions: From Disillusionment to Participation, Strasbourg, 27 - 28 November.

[8] Sanders, Luk. (2013)"Keyakinan Aneh dari Alexis de Tocqueville: Kristen sebagai Filsafat". International Journal of Philosophy and Theology , 74: 1 (2013): 33-53. (2013),

[9] Suhartono. (2009). Tingkat kesadaran Politik Pemilih Pemula dalam Pilkada; suatu Refleksi School-Based democracy Education (Studi Kasus Pilkada Provinsi Banten Jawa Barat). UPI. Bandung

[10] Sutanyo, AMA dan Machfiroh R. (2016), Political Marketing Activity In Simultaneous Regional Elections 2015. Jurnal MIMBAR Jurnal Sosial dan Pembangunan 33 (1), 99106

[11] Tapscott. (2010). The Politics of Youthful Antipolitics: Representing the 'Issue' of Youth Participation in Politics, Journal of Youth Studies, Vol. 13 (2): 181-195 (2010)

[12] UU nomor 7 tahun 2017 tentang Pemilu pasal $1 \quad$ ayat 34 https://news.idntimes.com/indonesia/linda/pil kada-2018-10-juta-pemilih-pemulaterancam-tak-bisa-memilih-1/full diunduh tanggal 4 Januari 2019. 